\title{
Review on Challenges and Opportunities of Poultry Breeds
}

\author{
Fulas Hinsemu ${ }^{1 *}$, Yohannis Hagos ${ }^{2}$, Yobsan Tamiru ${ }^{1}$ and Abriham Kebede ${ }^{2}$ \\ ${ }^{1}$ school of Veterinary Medicine, College of Medical And Health Science, Wollega University, P.O.Box, 395, Nekemte, Ethiopia \\ ${ }^{2}$ College of Veterinary Medicine, Mekelle University, Ethiopia
}

Submission: July 11, 2018; Published: August 08, 2018

*Corresponding author: Fulas Hinsermu, College of Veterinary Medicine, mekelle University, P.O. Box, 3006, mekelle, Ethiopia, Tel: +251-917-095-077 Email: yobsanraji@gmail.com

\begin{abstract}
Summary
Poultry production has important economic, social and cultural benefits and plays a significant role in family nutrition in the developing countries. It has been estimated that $80 \%$ of the poultry population in Africa are found in traditional scavenging system which makes substantial contributions to household food security throughout the developing world. Ethiopia has about $60 \%$ of the total chicken population of East Africa, which includes local, exotic and hybrid chicken breeds. About $97 \%$ of the Ethiopian poultry population consists of indigenous chickens, while the remaining 3\% consists of crossed and exotic breeds of chickens. All over the country, the indigenous chickens are an integral component of the livelihoods of most of rural, peri-urban, and some urban households and are likely to continue to meet this role for the foreseeable future. The indigenous chickens are characterized by slow growth, late maturity and low production performance. Due to these and other factors, there has been substantial efforts to introduce improved exotic chickens particularly introduction of Issa Brown (IB), Bovan Brown (BB), Babcock and dual-purpose hybrid Potchefstroom Koekoek (PK) breeds to the country by government and some Non-Governmental Organization with the aim of improving the existing indigenous breeds. Currently, Ethiopia is strengthening to increase facilities such as the animal health services, the training of beneficiaries in health and husbandry practice and on- and off-farm adaptive research on topics related to poultry production, being established of Poultry Multiplication and Distribution Centers and preparing supplying chain among the communities are the major best practices in improved poultry breed supply. Looking at the improved chicken supply model, the improved breeds are supplied by PMDC to Chicken growers, farmers or poultry farms, and Chicken growers take intermediate roles where they take day old chickens from the PMDC and then, sell them to farmers or farms after 40 days. However, the Ethiopian improved poultry breeds supply is still facing various challenges which constantly affect poultry farms and farmers. Therefore, the objective of this paper is to highlight the supply of improved poultry breeds supply and to discuss constraints in improved poultry breeds supply in Ethiopia.
\end{abstract}

Keywords: Challenges; Chicken Distribution; Improved breeds; Poultry; Chicken growers; Broilers; Hybrid; Exotic Breeds; Bovan Brown; Issa Brown; White leghorn; Feed producers; Meat; Egg

Abbreviations: IB: Issa Brown; BB: Bovan Brown; PK: Potchefstroom Koekoek; NGO: Non-Governmental Organization; PMDC: Poultry Multiplication and Distribution Centers; UARD: Urban and Rural Agricultural Departments; RIR: Rhode Island Red; DOC: Day-Old Chicks; IFAD: International Fund for Agricultural Development; NVI: National Veterinary Institute; ND: Newcastle disease; IBD: Infectious Bursal disease; MD: Marek disease

\section{Introduction}

Poultry production has an important economic, social and cultural benefit and plays a significant role in family nutrition in the developing countries. The proportional contribution of poultry to the total animal protein production of the world by the year 2020 is believed to increase to $40 \%$, the major increase being in the developing world [1]. It has been estimated that $80 \%$ of the poultry population in Africa are found in traditional scavenging systems [2]. In most tropical countries it is based mainly on scavenging production systems, which makes substantial contributions to household food security throughout the developing world [3]. The diverse agro ecology and agronomic practice prevailing in Ethiopia together with the huge population of livestock in general and poultry, could be a promising attribute to boost up the sector and increase its contribution to the total agricultural output as well as to improve the living standards of the poor livestock keepers [4].

Ethiopia has about $60 \%$ of the total chicken population of East Africa, which includes local, exotic and hybrid chicken breeds. About $97 \%$ of the Ethiopian poultry population consists of indigenous chickens, while the remaining 3\% consists of imported exotic and hybrid breeds of chickens [5]. Even though there is no recorded information which indicates when and by whom the first batch of exotic breeds of chickens were introduced to Ethiopia, the introduced improved chicken breeds have been found to play significant roles in human nutrition and as a source of income. The distribution and density of poultry of the country 
vary from place to place, but they are found in most parts of the country suitable for human settlement [6].

Indigenous breeds which vary in color, comb type, body conformation and weight still contribute meaningfully to poultry meat and egg production and consumption in the country, where they make up to $90 \%$ of the total poultry products of the country [7]. All over the country, these indigenous chickens are an integral component of the livelihoods of most of rural, periurban, and some urban households and are likely to continue to meet this role for the foreseeable future [8].

There has been a substantial effort to introduce improved exotic chickens particularly introduction of Isa Brown (IB), Bovan Brown (BB), broilers, Babcock and dual-purpose hybrid Potchefstroom Koekoek (PK) breeds to the country by government and some Non-Governmental Organization (NGO). However, lack of recorded data on the performance of chicken and all aspects of management, lack of regular chicken health program and market information makes it difficult to assess the importance and contributions of the past attempts to improve the sector [9].

With the aim of improving poultry productivity, different breeds of exotic chickens (Rhode Island Red, Australorp, New Hampshire and White Leghorns) were imported to Ethiopia since the 1950's. Since then higher learning institutions, research organizations, the Ministry of Agriculture and NonGovernmental Organizations (NGO's) have disseminated many exotic breeds of chicken to rural farmers and urban-based smallscale poultry producers. There is also selecting best local chicken based on growth and egg production for the breeding program and development of synthetic lines. These programs have been introduced courtesy of poultry multiplication and distribution centers (PMDC) and the Urban and Rural Agricultural Departments (URAD) with different systems of improving, multiplying and distributing improved poultry breeds to farmers and other bodies [10].

Currently, Ethiopia is strengthening to increase facilities such as the animal health services, the training of beneficiaries in health and husbandry practice and on- and off-farm adaptive research on topics related to poultry production, being established of Poultry Multiplication and Distribution Centers and preparing supplying chain among the communities are the major best practices in improved poultry breeds supply [11]. However, under this program, prevailing diseases, predators, lack of proper health care, poor feeding, less adaptively of exotic breeds, genetic dilution and poor marketing information were reported as constraint $[12,13]$.

The objective of this seminar paper is:

a. To highlight the supply of improved poultry breeds in Ethiopia.

b. To discuss the major constraints of improved poultry breeds supply in Ethiopia.

\section{Types of Poultry Breeds in Ethiopia}

Poultry include all domestic birds kept to human food (meat and eggs) production including chickens, ducks, ostrich, guinea fowl, doves and pigeons, of these chickens are the only domestic birds in Ethiopia. All over the world, more than 300 breeds of the domestic chicken species (Gallus domesticus) exist. There are three main categories of chicken breeds: pure commercial breeds, hybrid breeds resulting from cross-breeding and local breeds or land races. However, among the three chicken breed types indigenous chickens are dominant having large population size. While, those of exotics are insignificant in number in the country [14]. Formerly the exotic ones were kept only in commercial farms with intensive management and local or indigenous breeds in backyard chicken production systems. Currently, exotic/cross breeds are being kept in backyard chicken production systems with certain inputs [15].

\section{Indigenous (local) Breeds}

Table 1: Common ten (10) Ethiopian local chicken breeds/Ecotypes.

\begin{tabular}{|c|c|c|c|}
\hline & $\begin{array}{c}\text { Breed Name/Strain/ } \\
\text { Ecotype }\end{array}$ & $\begin{array}{c}\text { Common } \\
\text { Name/Synonym }\end{array}$ & Local Name \\
\hline 1 & Chefe & & \\
\hline 2 & $\begin{array}{l}\text { Gebsima (Graish mixture, } \\
\text { literally barely plumage } \\
\text { colour) }\end{array}$ & Gebsimadoro & Gebsimadoro \\
\hline 3 & Horro & & \\
\hline 4 & Jarso & & \\
\hline 5 & Kei (Red plumage color) & Kei doro & Kei doro \\
\hline 6 & Naked neck & & \\
\hline 7 & $\begin{array}{l}\text { Netch (White plumage } \\
\text { color) }\end{array}$ & Netchdoro & Netchdoro \\
\hline 8 & Tepi & & \\
\hline 9 & $\begin{array}{l}\text { Tikur (Black plumage } \\
\text { color) }\end{array}$ & Tikurdoro & Tikurdoro \\
\hline 10 & Tilili & Ye-Tilili Doro & \\
\hline
\end{tabular}

The Ethiopian indigenous chickens are non-descriptive breeds closely related to the Jungle fowl. They vary in color, comb type, body conformation, weight and may or may not possess shank feathers. Broodiness (maternal instinct) is pronounced. Indigenous chickens have an inherent scavenging and nesting habit, they are more resistant to diseases, less prone to predator attacks and can survive under harsh nutritional and environmental conditions. Hence, selection in local breeds is targeted at adaptation to harsh environments and resistance to disease rather than enhanced production. They are characterized by slow growth, late maturity and low production performance. The mean annual egg production of indigenous chickens is estimated at 60 small eggs with thick shells and a deep yellow yolk color [16]. Most of the urban and Peri-urban community keeps these indigenous breeds because they are well adapted to the current environmental condition. The egg laying period and number of eggs laid per period are to some extent higher in urban than in rural areas. The carcass weight of local chickens 
at 6 months of age was $559 \mathrm{~g}$ which was significantly lower than that of the $875 \mathrm{~g}$ found for Leghorn but higher in dressing percentage than exotic chickens [17].

Though Productivity of the local chicken breed was reported to be low these chickens can survive well with low input and the taste of their eggs and meats is flavorful [15]. Therefore, breed improvement and subsequent proper utilization of these local chicken genotypes strongly demands comprehensive characterization including, production system and breeding practice (Table 1).

\section{Commercial or Exotic Breeds}

Commercial breeds are developed based on the demand of consumers. Currently the commercial breeds are either layers or broilers. There are also pure, exotic breeds but currently they are not available in the commercial markets of Ethiopia. Formerly Rhode Island Red and White Leghorns were available in Ethiopia. We can roughly divide commercial breeds according to their main production aim as egg laying, mainly with lightweight laying breeds or layers; meat production, mainly by heavyweight breeds or broilers; both egg-laying and meat production by socalled dual-purpose breeds [18].

\section{Layers}

These breeds are used primarily for egg production. Most of the time, the eggs of the parent stock are imported. Then the generations are used for their egg production while the parent stock is used for hatchery purposes. Previously, several layer breeds were imported to Ethiopia, but currently there are just three of them used for egg production [15].

\section{Bovans Brown}

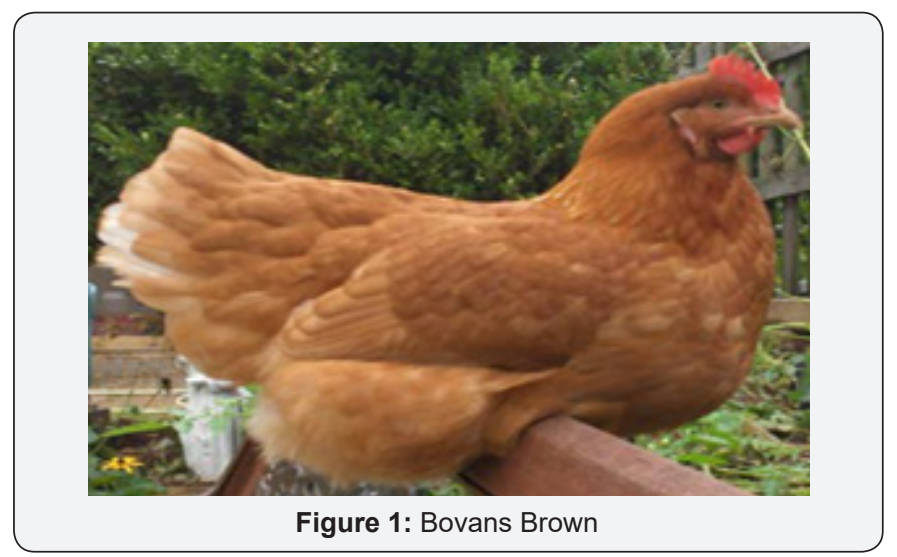

This breed was formerly known as Bovans Goldline and is a hybrid of Rhode Island Red (cock) and Light Sussex (hen). Bovans Brown is a brown feathered, brown egg layer which can meet the expectations of a variety of egg producers with different objectives (Figure 1). It is the bird of choice for today's egg farmers who expect high egg numbers and a forgiving bird essential ingredient to keeping business profitable. It not only performs well for the egg producer with traditional production facilities but is very docile making it's the perfect bird for alternative production methods as well.

\section{Issa Brown}

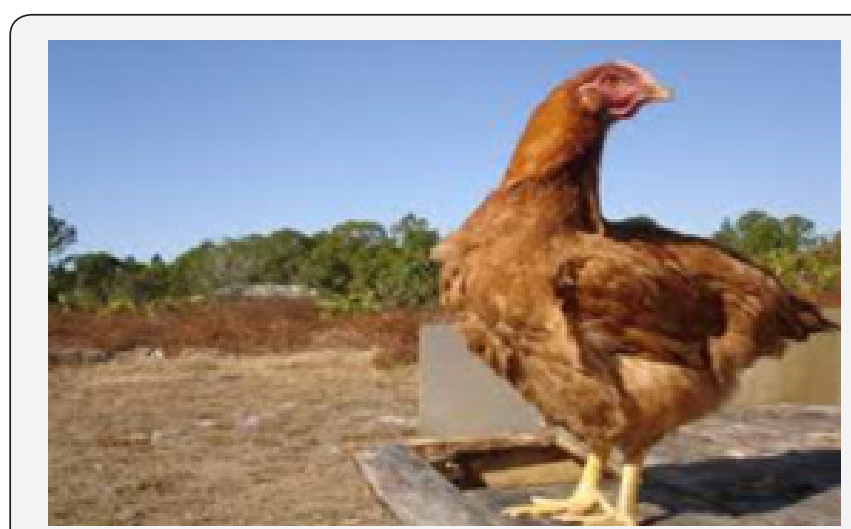

Figure 2: Issa Brown.

Like Bovans Brown, Issa Brown is also available in Ethiopia. This layer is a hybrid of Rhode Island Red (hen) and Rhode Island White (cock) (Figure 2). It is known for its high egg production of approximately 300 eggs per hen in the first year of lying. They are easy to rise and prolific producers of large richly colored brown eggs of excellent shell quality. They are quiet and friendly and easily trained to lay in their nest (Figure 2).

\section{White Leghorn}

White Leghorns are known for laying lots of white eggs. They need less feed, due to their small size. White Leghorns are therefore Very efficient layers. At the end of the laying period they give relatively little meat [19].

\section{Broilers}

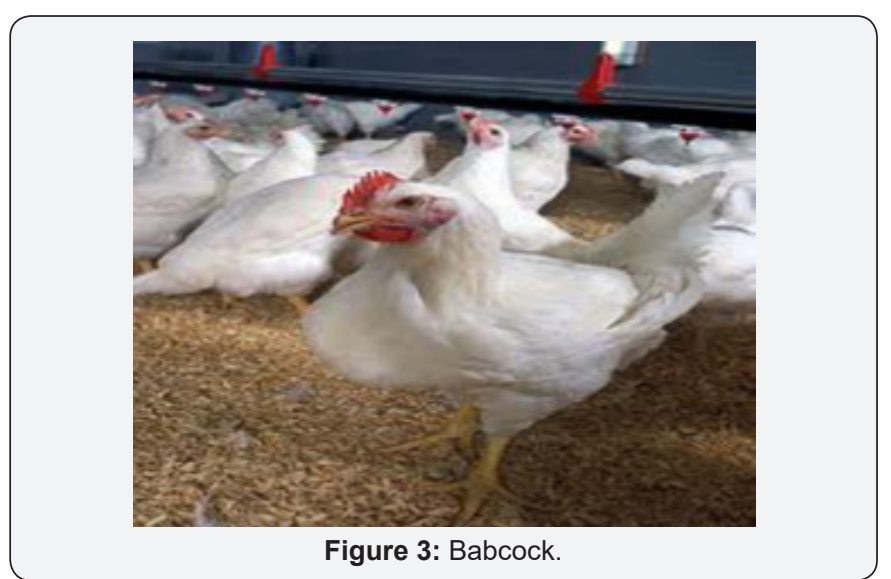

Broilers are chickens raised specifically for meat production. Modern commercial broilers are specially bred for large scale, efficient meat production and grow much faster than egg laying hens or traditional dual-purpose breeds. They are noted for having very fast growth rates, a high feed conversion ratio, and low levels of activity. Broilers often reach a harvest weight of 4-5 pounds dressed in only five weeks, although slower growing free-range and organic strains reach slaughter weight at 12-16 
weeks of age. Typical broilers have white feathers and yellowish skin. This cross is also favorable for meat production because it lacks the typical "hair" which many breeds have that necessitates singeing after plucking (Figure 3). Both male and female broilers are slaughtered for their meat. Babcock is the chicken breed that is currently imported in Ethiopia and used for fattening purpose [20].

\section{Dual Purpose}

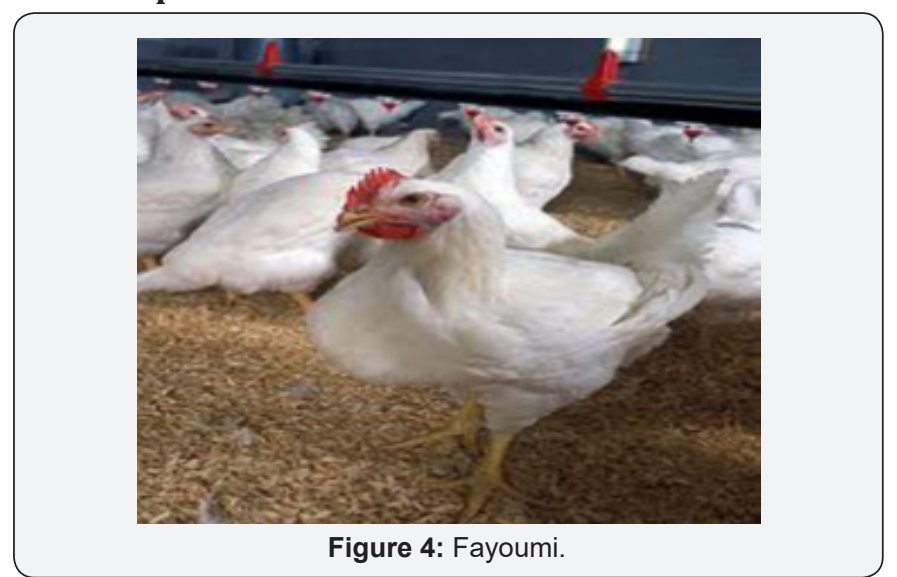

Additionally, there are chicken breed that is imported to Ethiopia from Egypt for trial purpose namely Fayoumi breed. They are known for their best adaptability in the harsh, hot and arid environment of Egypt and they have been in trial in lowlands of Ethiopia by Ethiopian Agriculture Research Institute. They are breeds of dual purpose and can be used both for egg production and meat. Since it is a short time they are introduce and still going on, there is no clear information about their performance in Ethiopia and they are only distributed in trial bases (Figure 4).

\section{Crossbreed/ hybrid}

Hybrids or cross-breeds result from combining special lines or strains of chickens developed for this purpose. An ongoing crossbreeding experiment is being conducted with the objective of producing dual purpose synthetic chicken for village poultry production in Ethiopia. The two exotic chicken breeds used were the Fayoumi (F) and Rhode Island Red (R) as dam line, whereas the two indigenous chicken breeds used were the Naked neck (N) and local Netch (W); a white feathered chicken. The indigenous breeds were used as sire line to produce the hybrids FN (FO X No') and RW (Ro X Wor). Growth and egg production performance of the crosses were compared with each other and with the exotic pure line performance [21].

\section{Poultry Breed Improving Activities in Ethiopia}

In the recent decades the demand for poultry and livestock products has been increased significantly that leads most to poultry-related development interventions promoting intensification of traditional poultry systems [22]. Traditional production methods dominate the market for birds, eggs and meat. However, during the past two decades, there has been gradual increase to commercial small and medium-scale flock production. This reflects the efforts of the Government of Ethiopia during the period since the early 1990s to boost the productive basis of domestic birds within a genetic improvement programme. These programmes have been introduced courtesy of poultry multiplication and distribution centers (PMDC) and the Urban and Rural Agricultural Departments.

There are different types of interventions to improve poultry breed to meet the existing poultry products demands.

\section{Introduction of Exotic Breed}

The most important inputs have been the introduction of improved (exotic) breed, [23]. Even if there is no recorded or evidence indicating the exact time and locations of introduction of the first batch of exotic breeds of chickens into Ethiopia for genetic improvement, it is widely believed that the importation of exotic breeds of chicken goes back to the early 1950s [24]. The past genetic improvement efforts of the Ethiopian village chicken via exotic chicken extension was constrained by lack of comprehensive poultry technology package extension to the end users $[25,26]$.

Adoption of improved poultry production practices may involve the transfer of appropriate new technologies and local experiences to be used in improving productivity of the stocks [25]. Currently, one of the extension options to attempt is the use of full packages jointly with improved exotic breeds that are better in terms of productivity. The Extension Department of the Ministry of Agriculture (MoA) of Ethiopia has shown more preference and interest in the use of the Rhode Island Red (RIR) breed that could serve as a dual-purpose for egg and meat production. Additionally, Fayoumi breed has been imported with the expectation of better productivity, adaptation and disease resistance than the other exotic breeds in rural setting of Ethiopia [27].

This introduction of exotic breeds can be occurred through importing Day-old chicks (DOC) which were either imported from Egypt, Germany, Holland and other countries, pure exotic pullets, Cockerels, Fertile eggs to farmers from abroad as well as to poultry breeding and multiplication centers. The common exotic breed may use as pure and/or for cross breed [19].

\section{Improving Indigenous Breeds}

Indigenous chicken (97\%) in Ethiopia is found in huge number being distributed across different agro-ecological zones and reared under a traditional family-based scavenging management system. Indigenous chickens are good scavengers as well as foragers and have high levels of disease tolerance, possess good maternal qualities and are adapted to harsh conditions and poor-quality feeds as compared to the exotic breeds. Moreover, Indigenous chickens provide major opportunities for increased protein production and income for smallholders. Therefore, providing the necessary support to the development of local chicken in rural areas is essential in improving nutritional status of the rural household [28]. 
Improvements of the genetic potential of the local chicken have been done through selection within and/or up grading with exotic breeds. The aim is to combine the adaptive attributes of the local with the high producing abilities of the exotic chickens. In Ethiopia, a local breed, Horro crossed with exotic breed fayoumi was reported to perform well even under extensive chicken management condition [29].

In scavenging production system chicks are left to move freely around the village with their hens from the first day of their life. Confinement housing, supplementary feeds, water and health care are rarely provided which attribute to high chick loss. Improving husbandry, especially confinement housing, supplementary feeds, water and health care should be provided which likely protect chicks from these major causes of death and to promote their productivity too [30].

\section{Poultry Breed Improving and Distributing Centers (PMDC)}

Poultry breeding and multiplication center is a center that selects new and improved types of poultry and conduct insemination by natural or artificial means. The center can supply improved breed of layers and broilers for poultry farms in the city and to the farmers in different areas. Some PMDCs have their own parent stock and hatchery facilities from which they multiply and distribute /supply improved chicken breeds to urban and rural areas. At the beginning, the PMDCs were mainly involved with distributing improved poultry breeds to farmers in rural areas, but with better links to urban agricultural departments and now they also distribute to urban and periurban areas as well. There are different private and government operated poultry multiplication and distribution centers through the country [31].

\section{Governmental Centers}

There are government-owned poultry breeding and rearing centers aimed at providing improved layer, broiler and dual-purpose chickens of exotic breeds. The Ethiopian higher education and research institutions run several modern poultry farms with the objectives of training and research. The institutions distribute fertile eggs, day-old chicks, pullets and cockerels for Ministry of Livestock, Feed and Drugs (MoLFD), NGOs and individuals. The MoLFD operates a total of 14 modern breeding and/ or rearing centers [32].

Governmental centers like, poultry multiplication and distribution centers (PMDC), the Urban and Rural Agricultural Departments (URAD), Agricultural Research Institutes such as Debre Zeit Agricultural Research Centre, introduce and distribute exotic breeds, provide improved extension advice and services and to generally exploit the capacity of the sector to boost rural productivity (with the implications of raising incomes and providing employment). There are more than 15 government owned poultry breeding and multiplication centers located at Mekelle (Tigray), Andassa, Kombolcha (Amhara), Adama, Fitche,
Ambo, Legatafo, Adelle, Bedelle, Nekemt (Oromiya), Awassa (SNNPR), Dire Dawa and Harar that mainly focus on Rhode Island Red breed (Figure 5).

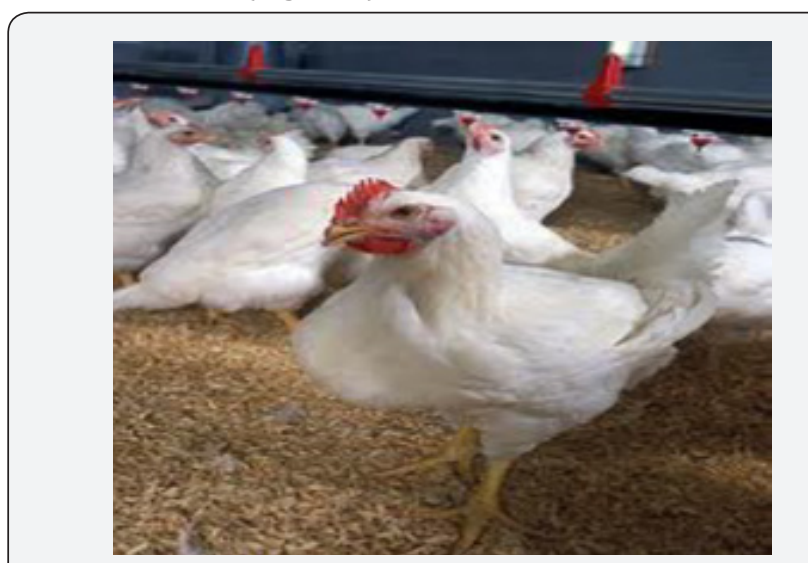

Figure 5: The map of regional poultry multiplication and distribution centers.

\section{Private Centers}

In Ethiopia, the private poultry enterprises are situated mostly in Busheftu areas and surrounding Addis Ababa. ELFORA, Alema, and Genesis farms are the major large-scale poultry enterprises located in Busheftu and Ethio-chicken PMDC in Mekelle with its branches throughout the country are the major private centers of PMDC [33].

\section{System of Distribution of Improved Poultry Breeds to Farmers and Other Bodies}

The PMDC methods of working are standardized and simple. They raise and multiply parent stock, which is imported as fertile eggs and/or DOCs. The F1 stock is then sold either as fertilized eggs, DOC or three-month-old growers/pullets. In the latter case, birds are vaccinated for NCD and Gumboro and, in some cases, against Marek's Disease. No other vaccination or treatments are scheduled during the subsequent production cycle. Only antibiotics and vitamins may be given when problems arise. All products of PMDCs are sold to farmers and small-scale farms with subsidized prices, which are usually around $50 \%$ below real market price [34].

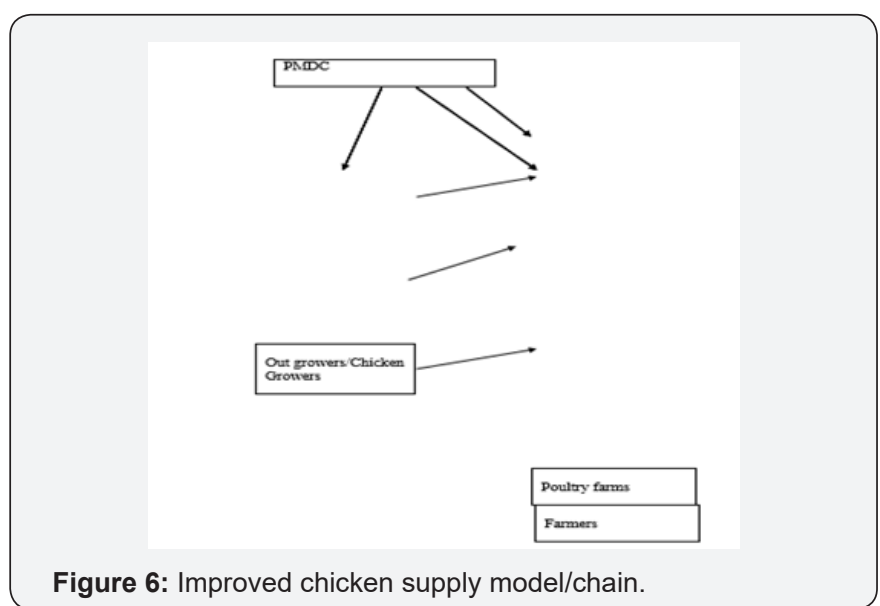


Importation of day-old chicks and hatching eggs from Egypt, Germany, Holland, Kenya, South Africa to Multiplication centers. Multiplication centers import and multiply to provide for rearing centers and some farms directly. By the turn after 1-3 months the rearing centers provide pullets and cockerels to agriculture office (Woreda), which supply and distributes improved breeds to farmer and small-scale farms (Figure 6) [35].

\section{Best Practices in Improved Poultry Breed Supply}

In comparison with government agricultural offices, NGOs often have more and better equipped field staff who can work together with communities. At present MoLFD is the organization mandated with poultry extension work. The Ministry poultry extension activities thus far have concentrated on breed improvement through distribution of exotic breeds. The ongoing national poultry extension package of the Ministry comprises of the distribution of 3-month-old exotic pullets and cockerels. The breeding multiplication centers are expected to rear chicks up to three months of age or even older before distribution to farmers but are unable to meet demand due to the huge requirement in terms of brooding facilities, despite having adequate hatching capacity. The ministry promoted a scheme whereby cockerels and pullets of Rhode Island Red (RIR) were distributed from the breeding and multiplication centers to subsistence farmers [36].

Recently MoARD drawn up development strategy for poultry and poultry products indicates that there are plans to bring about improvements through five key measures. The measures are the following which are: Properly delineating potential production areas; organizing producers into different specialized tasks and linking them up through market chains (e.g. fertile egg producers, hatchery and chick growers, pullet growers, broiler growers, feed producers, health care takers); improving input services (increasing the production capacity of existing poultrymultiplication centers, establishing new parent stock farms and chick-rearing centers); Establishing a new distribution style of focusing on potential villages that could create easy access to such input services as improved feed and health, rather than scattering efforts thinly over long distances and motivating private-sector participation in poultry development by linking commercial farms with small-holders in a market chain [36]. Especial the emergency of improved chicken breeds supply models, veterinary service and consultation supply, feed and equipment supply from PMDC to the farmers and some poultry farms and the presence of government intervention from region to Keble level for facilitating the system are the most important practices in developing the sector [37].

Numbers of NGOs and FAO are also involved in the implementation of poultry development projects to support vulnerable households. Donors and NGOs involved in training on household poultry and hay-box chick brooding technology and distribution of chicks of exotic breeds. They also assisted the implementation of national/regional training courses accompanied by the distribution of chicks and pullets/cockerels and to raise awareness on avian and human Influenza Small holder poultry production has been a frequent sub-component of several donor funded projects, for example the credit project of the International Fund for Agricultural Development (IFAD) targeting poorer rural women [38].

Currently, Ethiopia is strengthening animal health services, the training of beneficiaries in health and husbandry practice and on- and off-farm adaptive research on topics related to poultry production and developing importation of improved breed and strategies of multiplication and distribution to the farmers and other bodies [39].

In Ethiopia, the Australian V4 feed supplied vaccine for Newcastle Disease was tried on-station and on-farm through the FAO Rural Poultry Project by the National Veterinary Institute (NVI) with promising results. The development of the new heat tolerant vaccine that can be administered via feed opened up the possibility of significantly reducing mortality in village poultry, which should make producers more positive towards genetically improved birds and inputs to improve feeding and housing [40].

\section{Challenges in Improved Poultry Breeds Supply}

However, the Ethiopian poultry production and breeds supply is in advancing way, there are still challenges which constantly face poultry farms and farmers. Like feed availability and quality, disease and predators, extension problems, exotic chicken adaptation challenges, genetic dilution of local breeds and veterinary service shortages are the major today's poultry sector headaches [41].

\section{Feed Availability and Utilization}

Poultry feed and nutrition is one of the most critical constraints to poultry production under both the rural small holder and large-scale systems in Ethiopia. The problem is mainly associated with lack of processing facilities, inconsistent availability and distribution and sub-standard quality of processed feeds, when available [42]. There is no purposeful feeding of chickens under the village conditions in Ethiopia and scavenging is almost the only source of diet. Scavenging feed resource base for local birds are inadequate and variable depending on season.

The amount of feed available for scavenging in relation to the carrying capacity of the land areas and flock dynamics across the different seasons and agro ecologies is still not adequately quantified. However, studies conducted in three villages of the central highlands with different altitudes and in three different seasons revealed that the materials present in the crop, as visually observed are, seeds, plant materials, worms, insects and unidentified materials. Regular availability of good quality ingredients and a fully balanced complete feed are essential for efficient poultry production. The most serious problems arise from the unavailability of suitable micro-nutrient sources, vitamins and minerals [41]. 


\section{Disease and Predation}

Many reports showed that Newcastle disease (ND), Infectious Bursal disease (IBD) or Gumboro, Marek disease (MD), Fowl typhoid, Cholera, Mycoplasmosis and Coccidiosisare widely distributed in most African countries, Ethiopia is not exception to this situation [43]. The Ethiopian indigenous flocks are said to be relatively disease resistant and adapted to their environment. However, survival rates of chicks kept under natural brooding conditions is considered to be very low. Disease and predators are known to be the major causes of mortality in the country [44].

Losses attribute to Newcastle disease is estimated at about $57.3 \%$ of the overall annual chicken mortality whereas fowl pox, coccidiosis, and predation accounts for about 31.6\%, 9.4\%and $1.7 \%$ of the total annual flock mortality respectively. A survey conducted in Southern Ethiopia identified Fowl cholera followed by New Castle Disease, Coccidiosis, Fowl influenza (Infectious Bronchitis), Fowl pox, Fowl typhoid and Salmonella to be the major poultry diseases respectively.

The general indications are that the health status of the backyard poultry production system is very poor and risky, since scavenging birds live together with people and other species of livestock. Poultry movement and droppings are very difficult to control, and chickens freely roam in the compounds used by households and children. There are no practices (even means) of isolating sick birds from the household flocks and dead birds could sometimes be offered or left for either domestic or wild predators. The limitation of veterinary services such as drug, vaccine and consultancy to the rural farmers are the gaps for the occurrence of the loss due to diseases and predators [45].

\section{Adoption Challenges}

According to Ministry of Agriculture, in Ethiopia, like many African countries, attempts have been made at various times to improve local chicken production through introduction of exotic chicken breeds. Despite this huge distribution of exotic chicken breeds, the contribution of improved chicken breeds in the current production system of the region is very low. Some studies on the adoption of poultry technology in the highlands of Ethiopia indicated that adoption has been limited by a set of factors such as lack of knowledge on chicken husbandry (feeding, housing, health care, etc.), lack of complimentary inputs (feed, alternative breeds, etc.), environmental changes and highly susceptibility of chicken, lack of strong extension follow up and high disease prevalence [46].

\section{Inefficiency of Extension Education}

Lack of extension services is among the constraints that hinders development of poultry industry in developing countries. Although extension and research are well-organized systems that design and disseminate technological innovations to farmers, little emphasis has been given to local chicken research and extension [47]. Research conducted in Ethiopia revealed that extension linkage between research output and the ministry of livestock and the farmers are found to be extremely weak.

An absence of clear policy that defines the role of private and government institutions in relation to poultry production, processing and marketing; unclear roles and unfair competition from public sector constrains the entry of new producers to the sector and risks crowding out existing commercial producers, with spill-over effects on the entire chain [48].

\section{Imbalance Between Demand and Supply of Improved Chickens}

There is a chronic shortage supply of day old chicks, pullets and cockerels in Ethiopia. This leads to many farmers abandoning poultry keeping because their poultry houses will often be empty for months on end whilst they are waiting for new supplies from the hatcheries. Although the available hatching capacity is adequate; its performance is rather poor and needs improvement [49-52].

\section{Genetic Dilution of Local (Indigenous) Breeds}

The local chicken genetic resources in the Ethiopia were seriously endangered owing to the high rate of genetic erosion due to the extensive and random distribution of exotic chicken breeds, by both governmental and non-governmental organizations, since they are believed to dilute the indigenous genetic stock. Genetic dilution in indigenous poultry has been faster and wider due to their shorter generation interval [5357]. Rhode Island Red poultry has been distributed within almost all the Woredas of the country. Although crossbreeding was intended to raise productivity, most of the crossbreeding programs have failed to achieve their objectives at the farmer level because of the need for a high level of inputs.

\section{Conclusion and Recommendations}

Generally, it can be concluded that poultry production has an important economic, social and cultural benefit and has great role in family nutrition in Ethiopia. The country has huge chicken population which includes exotic, hybrid and indigenous through different agro ecological of the country. Indigenous breeds constitute huge $(97 \%)$ chicken population of the country with varying in phenotypical structure and supply the existing egg and meat demands in the community of the nation even though they have less productivity performance. There were different exotic chicken breeds imported with the aim of improving poultry productivity to Ethiopia since the 1950's. The past genetic improvement efforts of the Ethiopian village chicken via exotic chicken extension was constrained due to lack of adoption of improved poultry production practices which may involve the transfer of appropriate new technologies and local experiences to be used in improving productivity of the stocks. In addition to the introduction of exotic breeds, there is also improvement of the genetic potential of the local chicken through selection within or up grading with exotic breeds combining the adaptive attributes of the local with the high producing abilities of the 
exotic chickens. Poultry breed improvement and supply is carried out by government organizations and private centers. However, there are some constrains that still affect the system across the country with impact on the farmer's life. These constrains include feed availability problems, disease and predation, inefficiency of extension education, genetic dilution of indigenous and adoption challenges are the most common problems.

Based on the above conclusion, the following recommendations are forwarded:

a. Poultry breeding systems of the country should be improved to ensure the contribution of the sector in the development of the country.

b. Poultry multiplication and distribution centers should be increased throughout the country to meet the existing increasing demand for improved chicken breeds.

c. There should be standardized cross breeding methods of indigenous and exotic chicken breeds to minimize genetic dilution (Breeding policy is required).

d. Government should strengthen poultry extension and education to develop communities 'awareness towards poultry contribution in life.

e. Research on chicken breeds particularly, local breeds is highly recommended.

\section{References}

1. FAO (2010) Chicken genetic resources used in smallholder production systems and opportunities for their development. FAO Smallholder Poultry Production Paper, Rome, Italy, p. 5.

2. Dessalew T (2012) Management practices, productive performances and egg quality traits of exotic chickens under village production system. Msc. Thesis, Addis Ababa University College of veterinary medicine and agriculture, Bishoftu, in east shewa, Ethiopia. p. 1-2.

3. Takele T, Oli W (2012) Village chickens management in Wolaita zone of southern Ethiopia. Tropical Animal Health and Production 45(2): $22-41$.

4. Fessiha M (2009) Studies on production and marketing system of local chicken ecotypes in Bure Woreda, North west Amhara. M.Sc. Thesis, Hawassa University, Hawassa, Ethiopia, pp. 166.

5. CSA (2013) Agricultural sample survey. Report on livestock and livestock characteristics. The Federal Democratic Republic of Ethiopia, Private Peasant Holdings, Statistical Bulletin 570, Central Statistical Authority (CSA), Addis Ababa, Ethiopia.

6. Mekonnen G (2007) Characterization of smallholder poultry production and marketing system of Dale, wonsho and loka abaya weredas of southern Ethiopia. Msc. Thesis presentedto the School of Graduate Studies of Hawassa University p. 34-47.

7. Dana N, Tadelle D, Waaij L, Arendonk J (2010) Production objectives and trait preferences of village poultry producers of Ethiopia: implications for designing breeding schemes utilizing indigenous chicken genetic resources. Tropical Animal Health and Production 42(7): 1519-1529.

8. Besbes B (2009) Genotype evaluation and breeding of poultry for performance under suboptimal village conditions. World's Poult J Sci 65: 260-269.
9. Moges F, Mellesse A, Dessie T (2010) Assessment of village chicken production system and evaluation of the productive and reproductive performance of local chicken ecotype in Bure district, Northwest Ethiopia. African Journal of Agricultural Research 5(13): 1739-1748.

10. FAO (2008) Review of the new features of the Ethiopian poultry sector Biosecurity implications p. 5-7.

11. Gueye E (2009) The role of networks in information dissemination to family poultry farmers. World's Poultry Science Journal, 65: 115-123.

12. Dinka H, Chala R, Dawo F, Endale B, Samson L (2010) Major Constraints and Health Management of Village Poultry Production in Rift Valley of Oromia, Ethiopia. Global Veterinaria, 5(1): 6-10.

13. Mengesha M (2013) Review Biophysical and the socio-economics of chicken production. African Journal of Agricultural Research. 8(18): 1828-1836.

14. CSA (2011) Agricultural sample survey statistical bulletin 505. Report on livestock and livestock characteristics (prevent peasant holdings) Addis Ababa, February p. 21.

15. USAID (2012) Assessment of Available Birds in Ethiopia p. 1-4.

16. Yami A, Dessie T (1997) The Status of Poultry Research and Development in Ethiopia. In: Fifth National Conference of Ethiopian Society of Animals Production (ESAP), Addis Ababa Ethiopia p: 40-60.

17. Fessiha M, Azage T, Tadelle D (2010) Indigenous chicken production and marketing system in Ethiopia, characteristics and opportunities for market -oriented development, Ethiopia.

18. VanEekeren N, Maas A, Saatkamp Hand Verschuur M (2006) Agrodok Hand book of Small-scale chicken production. ( $4^{\text {th }}$ edn), p. 9.

19. Haftu K (2016) A Review Exotic Chicken Status, Production Performance and Constraints in Ethiopia. Asian Journal of Poultry Science, 10: 30-39.

20. McKay J (2008) The genetics of modern commercial poultry. Proceedings of the 23rd World's Poultry Congress, Brisbane, Australia p. 48.

21. Fasill B, Hans Gjoen J, Tormod A, Girma A (2010) Production performance of dual purpose crosses of two indigenous with two exotic chicken breeds in sub-tropical environment. Inter Pout Sci 9: 702-710.

22. FAO (2009) The State of Food and Agriculture. Livestock in Balance p. 59-72.

23. Tamirat D (2015) Overview and background paper on Ethiopia's poultry sector Relevance for HPAI research in Ethiopia. ILRI report p. 17.

24. Avery A (2004) Red Meat and Poultry Production and Consumption in Ethiopia and Distribution in Addis Ababa. ILRI.

25. Teklewold H (2006) Determinants of adoption of poultry technology: a double-hurdle approach. Livestock Research for Rural Development 18(3): 115-127.

26. Reta D (2009) Understanding the role of indigenous chicken during the long walk to food security in Ethiopia. Livestock Research for Rural Development 21(8): 56-82.

27. Wilson R (2010) Poultry production and performance in the Federal Democratic Republic of Ethiopia. World's Poult Sci J 66: 132-149.

28. Addisu H, Hailu M, Zewdu W (2013) Indigenous Chicken Production System and Breeding Practice in North Wollo, Amhara Region, Ethiopia. Cholarly Journal of Agricultural Science 3(10): 433-444.

29. Matiwos H, Negassi, Solomon D (2013) Production performance of local and exotic breeds of chicken at rural household level in NoleKabba Woreda, Western Wollega, Ethiopia. African Journal of Agriculture Research 8(11): 1014-1021. 
30. Khandait V, Gawande S, Lohakare A, Dhenge S (2011) Adoption Level and Constraints in Backyard Poultry Rearing Practices at Bhandara District of Maharashtra (India). Research Journal of Agricultural Sciences 2(1): 110-113.

31. Solomon D (2007) Suitability of hay-box brooding technology to rural household poultry Production system. Jimma University College of Agriculture and Veterinary Medicine, Jimma, Ethiopia p. 41.

32. Demeke S (2007) The Structure, Marketing and Importance of the commercial and village Poultry industry. An analysis of poultry sector in Ethiopia FAO report p: 12-30.

33. Bush J (2006) The threat of Avian Flu: predicted impacts on rural livelihoods in SNNPR in Addis Abeba, Ethiopia.

34. Abebe W (2008) Review of the new features of the Ethiopian poultry sector Biosecurity implications, Addis Ababa, Ethiopia. A consultancy report to FAO, p: 22-46.

35. Nzietcheung S (2008) Characterization of poultry production systems and potential pathways for the introduction of highly pathogenic avian influenza in Ethiopia. Draft Report. International Livestock Research Institute p: 68-72.

36. MoARD (2010) Ethiopia's Agricultural Sector policy and Investment Framework (PIF), Ethiopia.

37. www.Ethio-chicken (2015)

38. Jobre Y (2007) Urgent intervention for the early detection, prevention and control of Avian Influenza in Ethiopia.

39. Aklilu H (2007) Village poultry in Ethiopia; socio-technical analysis and learning with farmers. PhD Thesis, Wageningen University, Wageningen, the Netherlands.

40. FAO (2013) Ethiopian poultry mission to the Netherland p. 1-3.

41. Dessie T, Esatu W, Waaij L, Zegeye F, Gizaw S, et al. (2013) Village Chicken Production in the Central and Western Highlands of Ethiopia. FAO report p: 43-65.

42. Tadelle D, Negussie D, Alemu, Peters K (2002) The feed resource base and its potentials for increased poultry production in Ethiopia. World's Pout Sci J 58: 77-87.

43. Alem T (2014) Production and reproduction performance of rural poultry in lowland and midland agro-ecological zones of central Tigray, Northern Ethiopia. African Journal of Agriculture 9(49): 3531-3539.

44. Negussie D (2011) Breeding programs for indigenous chicken in Ethiopia, Analysis of diversity in production systems and chicken populations PhD. Thesis submitted in fulfillment of the requirements for the degree of doctor at Wageningen University Netherlands pp. 148.

45. Tadelle D (2015) Participatory evaluation of chicken health and production constraints in Ethiopia.Preventive Veterinary Medicine 118 (11): 117-127.

46. Fessiha M, Molla H, Simegnew T, Yeshiwas T (2015) Determinants of adoption of exotic poultry breeds among smallholder poultry producers in North Western Amhara Region, Ethiopia. Global Journal of Agricultural Econometrics 3(6): 162-168.

47. Ali S (2012) Family Poultry as a Tool in Alleviating Environmental Hazards in Settled Areas of Transhumant Families in Gezira Scheme Sudan. Asian Journal of Rural Development 2: 1-12.

48. LSA (2014) Ethiopia livestock master plan and livestock sector analysis, Addis Ababa, Ethiopia p. 64-78.

49. Mebratu L (2015) Investment opportunities in the EthiopianPoultry. Hatchery research on Business Opportunity Report p. 15

50. Demeke S (2004) Egg production performance of local and White Leghorn hens under intensive and rural household conditions in Ethiopia. Livestock Res. Rural Dev 16: 18-31.

51. Fessiha M (2009) Studies on production and marketing systems of local chicken ecotypes in bure Woreda, north-west Amhara Regional State, Hawassa University, Ethiopia.

52. Gueye E (2000) The role of family poultry in poverty alleviation, food security and the promotion of gender equality in rural Africa. Outlook on Agri 29(2): 129-136.

53. ILRI (2013) (International Livestock Research Institute), Strategies to improve village chicken Production report, Nairobi, Kenya p. 72.

54. Mazengia H, Siraw G, Nega M (2012) Challenge and prospects of village-based exotic chicken development strategy in Amhara regional state, Northwest Ethiopia. Global J. Sci. front. Res Agric Vet Sci 12: 121 123.

55. Tadelle D (2013) Village poultry production systems. Challenges and opportunities in achieving food security. International Livestock Research Institute report p. 23

56. Tadelle D, Ogle B (2000) Nutritional status of village poultry in the central high lands of Ethiopia as assessed by analyses of crop contents. Eth J Agri Sci 17: 47-57.

57. www NP nd (2012) Domestic Animal Genetic resource information system

Your next submission with Juniper Publishers will reach you the below assets

- Quality Editorial service

- Swift Peer Review

- Reprints availability

- E-prints Service

- Manuscript Podcast for convenient understanding

- Global attainment for your research

- Manuscript accessibility in different formats

( Pdf, E-pub, Full Text, Audio)

- Unceasing customer service

Track the below URL for one-step submission https://juniperpublishers.com/online-submission.php 